OPEN ACCESS

Edited by:

Keith Murai,

McGill University, Canada

Reviewed by:

Rafael Linden,

Universidade Federal do Rio de

Janeiro, Brazi

Michelle A. Clark,

Nova Southeastern University,

United States

*Correspondence: Liang Peng

sharkfin039@163.com

Received: 24 July 2017 Accepted: 11 October 2017 Published: 31 October 2017

Citation:

Li B, Jia S, Yue T, Yang L, Huang C, Verkhratsky $A$ and Peng $L$

(2017) Biphasic Regulation of

Caveolin-1 Gene Expression by

Fluoxetine in Astrocytes: Opposite Effects of PI3K/AKT and MAPK/ERK Signaling Pathways on c-fos.

Front. Cell. Neurosci. 11:335.

doi: 10.3389/fncel.2017.00335

\section{Biphasic Regulation of Caveolin-1 Gene Expression by Fluoxetine in Astrocytes: Opposite Effects of PI3K/AKT and MAPK/ERK Signaling Pathways on c-fos}

\author{
Baoman $\mathrm{Li}^{1}$, Shu Jia ${ }^{1}$, Tingting Yue ${ }^{1}$, Li Yang ${ }^{1}$, Chen Huang ${ }^{1}$, Alexej Verkhratsky ${ }^{2,3}$ \\ and Liang Peng ${ }^{1 \text { * }}$ \\ 'Laboratory of Metabolic Brain Diseases, Institute of Metabolic Disease Research and Drug Development, China Medical \\ University, Shenyang, China, ${ }^{2}$ Faculty of Life Science, The University of Manchester, Manchester, United Kingdom, \\ ${ }^{3}$ Achucarro Center for Neuroscience, IKERBASQUE, Basque Foundation for Science, Billbao, Spain
}

Previously, we reported that fluoxetine acts on 5- $\mathrm{HT} 2 \mathrm{~B}$ receptor and induces epidermal growth factor receptor (EGFR) transactivation in astrocytes. Recently, we have found that chronic treatment with fluoxetine regulates Caveolin-1

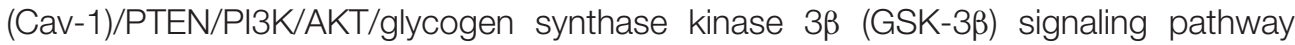
and glycogen content in primary cultures of astrocytes with bi-phasic concentration dependence. At low concentrations fluoxetine down-regulates Cav-1 gene expression, decreases membrane content of PTEN, increases PI3K activity and increases phosphorylation of GSK-3 $\beta$ and increases its activity; at high concentrations fluoxetine acts on PTEN/PI3K/AKT/GSK-3 $\beta$ in an inverse fashion. Here, we present the data indicating that acute treatment with fluoxetine at lower concentrations down-regulates c-Fos gene expression via PI3K/AKT signaling pathway; in contrast at higher concentrations fluoxetine up-regulates c-Fos gene expression via MAPK/extracellularregulated kinase (ERK) signaling pathway. However, acute treatment with fluoxetine has no effect on Cav-1 protein content. Similarly, chronic effects of fluoxetine on Cav-1 gene expression are suppressed by inhibitor of PI3K at lower concentrations, but by inhibitor of MAPK at higher concentrations, indicating that the mechanism underlying bi-phasic regulation of Cav-1 gene expression by fluoxetine is opposing effects of PI3K/AKT and MAPK/ERK signal pathways on c-Fos gene expression. The effects of fluoxetine on Cav-1 gene expression at both lower and higher concentrations are abolished by AG1478, an inhibitor of EGFR, indicating the involvement of $5-\mathrm{HT}_{2 \mathrm{~B}}$ receptor induced EGFR transactivation as we reported previously. However, PP1, an inhibitor of Src only abolished the effect by lower concentrations, suggesting the relevance of Src with PI3K/AKT signal pathway during activation of EGFR.

Keywords: astrocyte, Cav-1, cfos, PI3K/AKT, MAPK/ERK 


\section{INTRODUCTION}

Astroglial contribution to major depression (similarly to other psychiatric pathologies-see Verkhratsky et al., 2014) does not involve astrogliosis and hypertrophy being mainly manifested by a decrease in astroglial numbers and their hypotrophy. Previously we found that fluoxetine, as well as other selective serotonin reuptake inhibitors (SSRIs) act as agonists of $5-\mathrm{HT}_{2 \mathrm{~B}}$ receptors in astrocytes ( $\mathrm{Li}$ et al., 2008; Zhang et al., 2010; Peng et al., 2016). Astrocytes in cultures and in the brain in vivo express high level of $5-\mathrm{HT}_{2 \mathrm{~B}}$ receptors (Peng and Huang, 2012). The $5-\mathrm{HT}_{2 \mathrm{~B}}$ receptors are $\mathrm{Gq} / 11$ protein coupled and stimulation of these receptors generates diacyglycerol (DAG) and inositol 1,4,5-triphosphate $\left(\mathrm{InsP}_{3}\right)$. The latter triggers an increase of intracellular calcium concentration $\left(\left[\mathrm{Ca}^{2+}\right]_{\mathrm{i}}\right)$, which in turn activates $\mathrm{Zn}^{2+}$-dependent metalloproteinases and leads to shedding of growth factor(s) (for review see Peng and Huang, 2012). Subsequently, the released growth factors activate epidermal growth factor receptors (EGFRs). The downstream target of EGFR, extracellular-regulated kinase (ERK) is phosphorylated via the Ras/Raf/MEK pathway, and AKT is phosphorylated via PI3K pathway. Phosphorylation of AKT and ERK occurs in a few minutes after fluoxetine administration, and lasts only for $40 \mathrm{~min}$ ( $\mathrm{Li}$ et al., 2008; Bai et al., 2017). However, both pathways may induce long-term modification of astrocytic functions via regulation of gene expression (Li et al., 2008; Hertz et al., 2012, 2014).

Caveolin-1 (Cav-1), a scaffolding/regulatory protein, is an essential structural constituent of caveolae, which are flaskshaped invaginations of cell membrane (Lajoie and Nabi, 2010; Takizawa et al., 2013). The putative functions of Cav-1 are cholesterol transport (Yue and Mazzone, 2011) and endocytosis (Moskovich et al., 2012). In addition, Cav-1 modulates signal transduction by linking signaling molecules and thus regulating their downstream activity (Zebrowski et al., 1994). Caveolae, as well as caveolin protein are present in astrocytes (Cameron et al., 1997) where they contribute to lipid metabolism, endocytosis and signal transduction (Silva et al., 2007). Recently, we have found that chronic treatment with fluoxetine modifies Cav-1/PTEN/PI3K/AKT/GSK-3 $\beta$ signaling pathway (where PTEN stands for phosphatase and tensin homolog, and GSK-3 for glycogen synthase kinase 3) in primary cultures of astrocytes with bi-phasic concentration dependence (Bai et al., 2017). The GSK-3, the downstream substrate of AKT, is an enzyme, which has been initially discovered as a deactivator of glycogen synthase (GS) that converts glucose to glycogen. In addition, GSK-3 $\beta$ is involved in diverse signaling pathways. At lower concentrations fluoxetine down-regulates gene expression of Cav-1. The Cav-1 contains sequences for PTEN binding (Xia et al., 2010), and hence the down-regulation of Cav-1 expression reduces membrane content of PTEN, increases activity of PI3K/AKT, and elevates GSK-3 $\beta$ phosphorylation thus suppressing its activity. At higher concentrations fluoxetine acted in an inverse fashion (Bai et al., 2017). This outcome of chronic treatment is distinct from the acute effects of fluoxetine on AKT and ERK phosphorylation, which is directly proportional to the concentration of the drug (Li et al., 2008; Bai et al., 2017).
To understand mechanisms underlying bi-phasic concentration dependence of Cav-1 expression by fluoxetine, we have investigated: (i) effects of inhibitors of PI3K and MAPK on AKT and ERK phosphorylation induced by acute treatment with fluoxetine; (ii) effects of inhibitors of PI3K and MAPK on mRNA and protein expression of $c F o s$ and FosB in response to acute treatment with fluoxetine; (iii) effects of inhibitors of EGFR and Src on expression of Cav-1 mRNA and protein during chronic treatment with fluoxtine; (iv) effects of inhibitors of PI3K and MAPK on mRNA and protein expression of Cav-1 mRNA and protein in response to chronic treatment with fluoxtine; and (v) effects of inhibitors of PI3K and MAPK on glycogen content in response to chronic treatment with fluoxtine in primary astroglial cultures.

\section{MATERIALS AND METHODS}

\section{Animals}

Newborn CD-1 mice (Charles River, Beijing, China) were used for primary cultures of astrocytes. All experiments were carried out in accordance with the USA National Institute of Health Guide for the Care and Use of Laboratory Animals, and all experimental protocols were approved by the Institutional Animal Care and Use Committee of China Medical University.

\section{Cell Cultures}

Primary cultures of astrocytes were prepared as previously described (Hertz et al., 1998). The neopallia of the cerebral hemispheres of newborn CD-1 mice were aseptically isolated, vortexed to dissociate the tissue, filtered through nylon meshes with pore sizes of $80 \mu \mathrm{m}$ and subsequently $10 \mu \mathrm{m}$, diluted in culture medium, and planted in Falcon Primaria culture dishes. The culture medium was a Dulbecco's Minimum Essential Medium (DMEM) with $7.5 \mathrm{mM}$ glucose, initially containing 20\% horse serum, and the cultures were incubated at $37^{\circ} \mathrm{C}$ in a humidified atmosphere of $\mathrm{CO}_{2}$ /air $(5: 95 \%)$. The culture medium was exchanged with fresh medium of similar composition on day 3, and subsequently every 3-4 days. From day 3, the serum concentration was reduced to $10 \%$, and after the age of 2 weeks, $0.25 \mathrm{mM}$ dibutyryl cyclic AMP (dBcAMP) was included in the medium, leading to morphological and functional differentiation (Meier et al., 1991). The cultures were used after at least 3 weeks of culture.

\section{Drug Treatment}

\section{Acute Drug Treatment}

For determination of phosphorylation of $\mathrm{ERK}_{1 / 2}$ and $\mathrm{AKT}$, gene expression of $\mathrm{c}$-fos and fosB, and $\mathrm{Cav}-1$ protein content, cells were incubated in the culturing medium without serum at $37^{\circ} \mathrm{C}$ for $20 \mathrm{~min}, 1 \mathrm{~h}$ or $4 \mathrm{~h}$ in the absence or presence of $0.1,0.5,1,5$, or $10 \mu \mathrm{M}$ fluoxetine.

\section{Chronic Drug Treatment}

For determination of gene expression of Cav-1 and glycogen content, cells were treated with fluoxetine at $0,0.1,0.5,1,5$, or 
$10 \mu \mathrm{M}$ in the culturing medium with $10 \%$ serum at $37^{\circ} \mathrm{C}$ for 2 weeks.

\section{Western Blotting}

Samples containing $50 \mu \mathrm{g}$ protein were applied on slab gels of $10 \%$ polyacrylamide. The nitrocellulose membranes were incubated with the first antibody, specific to either Cav-1 or $\beta$-actin, and specific binding was detected by goat-antimouse or goat-anti-rabbit horseradish peroxidase-conjugated secondary antibody (Li et al., 2008). Band density was measured with Window AlphaEaseTM FC 32-bit software. Ratio was determined between scanned Cav- 1 and $\beta$-actin. Representative original images for the antibodies used in this study are shown in Supplementary Figure S1.

\section{Reverse Transcription-Polymerase Chain Reaction (RT-PCR)}

For determination of mRNA expression by RT-PCR, a cell suspension was prepared, the RNA pellet was precipitated, and RT was performed as previously described (Kong et al., 2002). PCR amplification was performed as described by $\mathrm{Li}$ et al. (2008) in a Robocycler thermocycler with sense (5'ACCTAGCCGTGGAGCTTGG-3 $3^{\prime}$ and antisense (5'GCCCTTGGTTGTTTACCTGG-3') for cfos (Elkeles et al., 1999), with sense (5'-AGCTGACAGCATGAAGGTCCTCC-3') and antisense (5'-TTCTGGGTGAAGACAGAAGGGCC- $\left.3^{\prime}\right)$ for fosB (Inoue et al., 2004), with sense (5'-CTACAA GCCCAACAACAAGGC- $3^{\prime}$ ) and antisense (5'-AGGAAG CTCTTGATGCACGGT-3') for Cav-1 (Hsieh et al., 2013) or with sense ( $5^{\prime}$-CCACGGACAACTGCGTTGAT- $\left.3^{\prime}\right)$ and antisense (5'-GGCTCATAGCTACTGAACTG-3') for TBP (Marjou et al., 2000), used as a housekeeping gene.

\section{Determination of Glycogen}

For determination of glycogen in cultured astrocytes, recording fluorescence intensity of NADPH generated from $\mathrm{NADP}^{+}$ as our previously described (Bai et al., 2017). Briefly, after 2 weeks treatment with normal saline (NS) or fluoxetine in the absence or presence of U0126 or LY294002, the astrocytes were washed three times with ice-cold phosphatebuffered saline (PBS) and sonicated in $30 \mathrm{mM} \mathrm{HCl}$. The suspension was used to measure non-hydrolyzed glycosyl units of glycogen. The fluorescence of the NADPH formed in amounts equivalent to glucose metabolized by hexokinase was read (excitation $340 \mathrm{~nm}$; emission $450 \mathrm{~nm}$ ). The sum of glucose and glucose-6-phosphate and the left glycosyl units from glycogen were separately measured, and the difference between these two aliquots was calculated. Meanwhile, the standard curve was made to show fluorescence intensity at different glucose concentrations and glycogen content was calculated which was normalized by protein content (per mg).

\section{Materials}

Chemicals for preparation of medium and most other chemicals, including fluoxetine, first antibody raised against
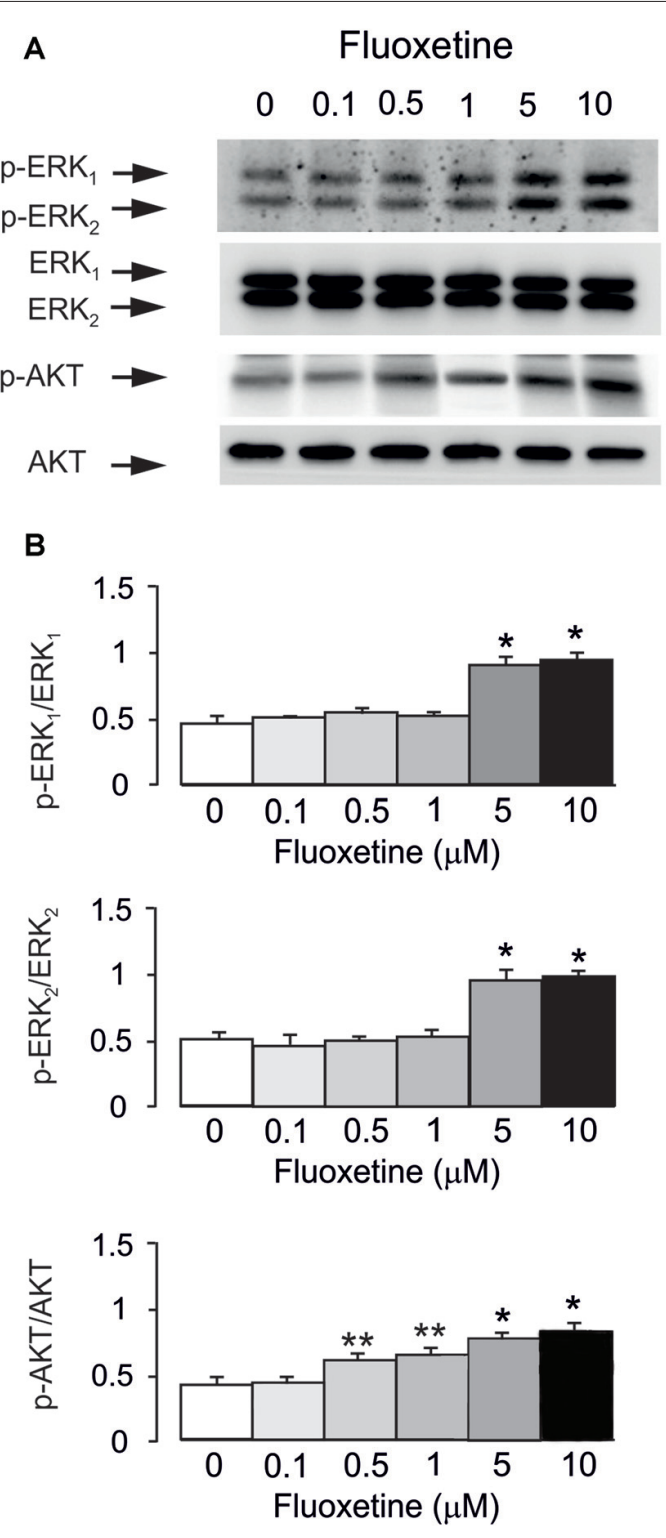

FIGURE 1 | Acute treatment with fluoxetine induced extracellular-regulated kinase $(E R K)_{1 / 2}$ and AKT phosphorylation in astrocytes. Cells were incubated for $20 \mathrm{~min}$ in the absence of any drug ( $0 \mu \mathrm{M}$ fluoxetine, control) or in the presence of $0.1,0.5,1,5$, or $10 \mu \mathrm{M}$ fluoxetine. (A) Immunoblot from a representative experiment. Similar results were obtained from three independent experiments. Average ERK phosphorylation was quantitated as ratios between $\mathrm{p}-\mathrm{ERK}_{1}$ and $\mathrm{ERK}_{1}$ and between $\mathrm{p}-\mathrm{ERK}_{2}$ and $E R K_{2}$, or average AKT phosphorylation was quantitated as ratio between $p-A K T$ and AKT (B). SEM values are indicated by vertical bars. *Indicates statistically significant $(P<0.05)$ difference from $0,0.1,0.5$ and $1 \mu \mathrm{M}$ fluoxetine; **indicates statistically significant $(P<0.05)$ difference from all other groups but not from each other.

$\beta$-actin, LY294002 (2-(4-Morpholinyl)-8-phenyl-1(4H)benzopyran-4-one hydrochloride), and PP1 (4-amino-5-(4methylphenyl)-7-(t-butyl)pyrazolo-d-3,4-pyrimidine) were purchased from Sigma (St. Louis, MO, USA). AG 1478 (N-[(2R)-2-(hydroxamidocarbonymethyl)-4-methylpentanoyl]Ltryptophan methylamide) was obtained from Calbiochem, 
A Fluoxetine U0126+Fluoxetine LY294002+Fluoxetine $\begin{array}{llllllllllllllllll}0 & 0.1 & 0.5 & 1 & 5 & 10 & 0 & 0.1 & 0.5 & 1 & 5 & 10 & 0 & 0.1 & 0.5 & 1 & 5 & 10\end{array}$
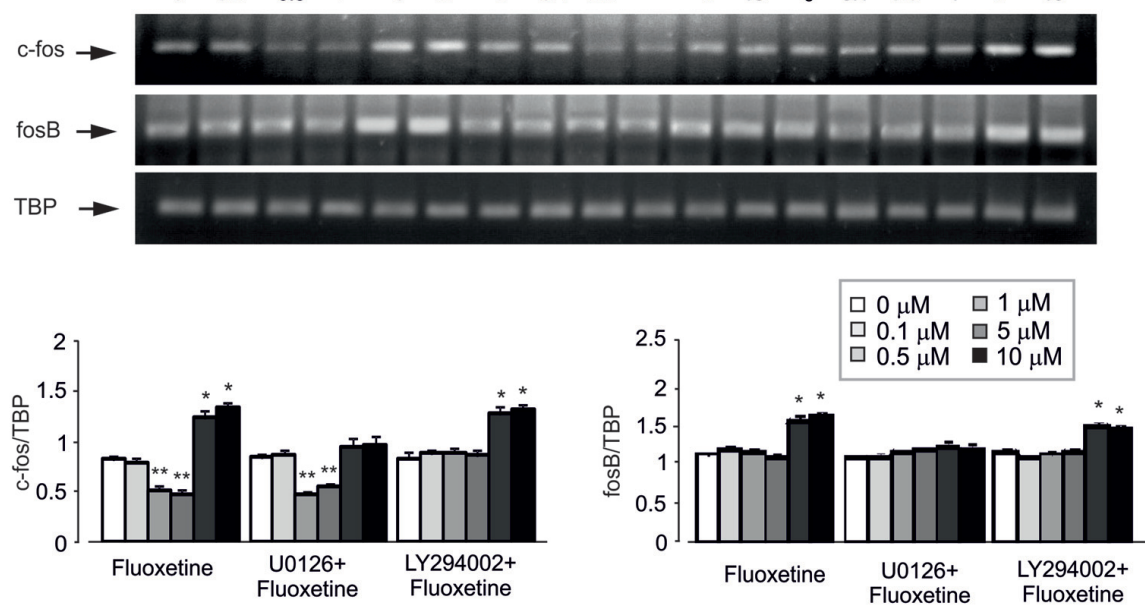

B

Fluoxetine

U0126+Fluoxetine

LY294002+Fluoxetine

$\begin{array}{llllll}0 & 0.1 & 0.5 & 1 & 5 & 10\end{array}$

$\begin{array}{llllll}0 & 0.1 & 0.5 & 1 & 5 & 10\end{array}$

$\begin{array}{llllll}0 & 0.1 & 0.5 & 1 & 5 & 10\end{array}$
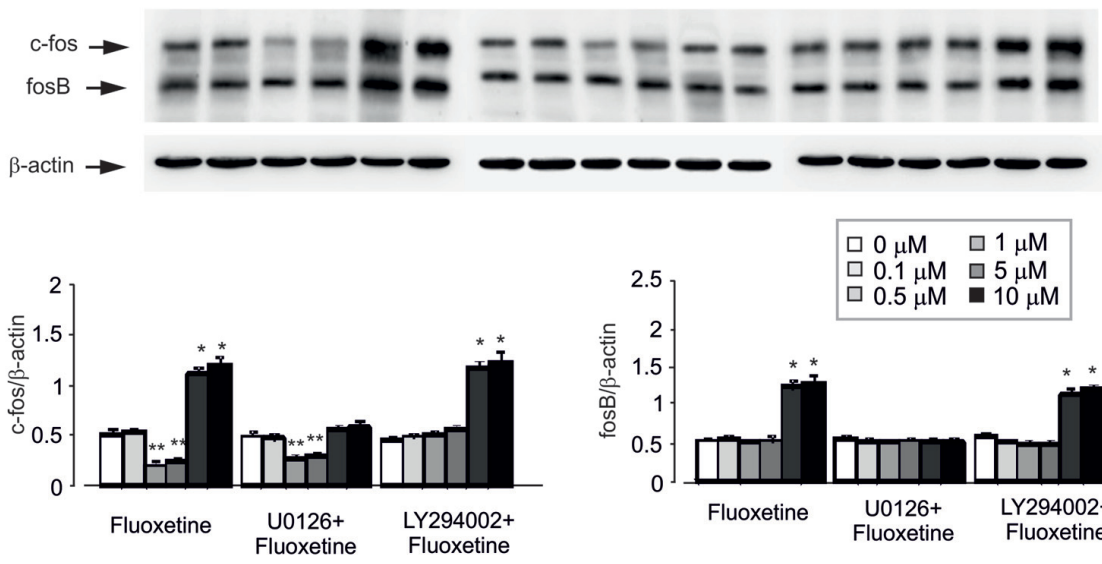

C

Fluoxetine
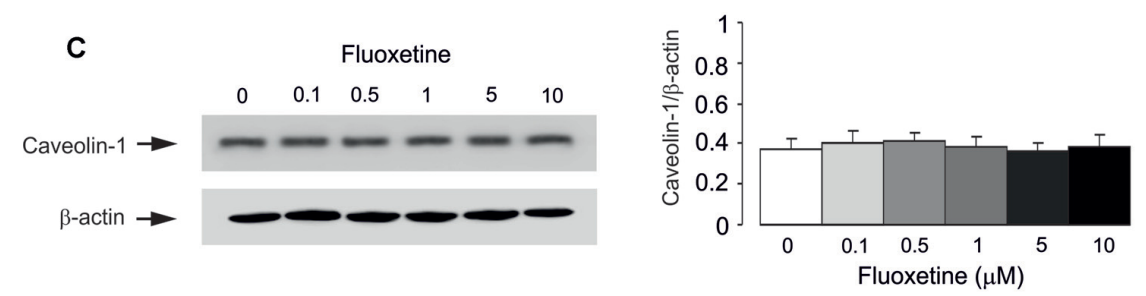

FIGURE 2 | Regulation of mRNA and protein expression of cfos and fosB or protein content of Caveolin-1 (Cav-1) by acute treatment with fluoxetine in astrocytes. (A,B) After pretreatment in serum-free medium with or without U0126, an inhibitor of MEK or LY294002, an inhibitor of Pl3K for 15 min, cells were incubated for 1 or $4 \mathrm{~h}$ in the absence of any drug ( $0 \mu \mathrm{M}$ fluoxetine, control) or in the presence of $0.1,0.5,1,5$, or $10 \mu \mathrm{M}$ fluoxetine. (A) Southern blot from representative experiment. Similar results were obtained from three independent experiments. Average mRNA expression was quantitated as ratios between c-fos and TBP, used as a house-keeping gene and between fosB and TBP. (B) Immunoblot from a representative experiment. Similar results were obtained from three independent experiments. Average protein expression was quantitated as ratios between c-Fos and $\beta$-actin, used as a house-keeping gene and between FosB and $\beta$-actin. SEM values are indicated by vertical bars. *Indicates statistically significant $(P<0.05)$ difference from $0,0.1,0.5$ and $1 \mu \mathrm{M}$ fluoxetine; **indicates statistically significant $(P<0.05)$ difference from all other groups but not from each other. (C) Cells were incubated for 1 or $4 \mathrm{~h}$ in the absence of any drug $(0 \mu \mathrm{M}$ fluoxetine, control) or in the presence of $0.1,0.5,1,5$, or $10 \mu \mathrm{M}$ fluoxetine. Left panel shows the immunoblot from a representative experiment. Similar results were obtained from three independent experiments. Average protein expression was quantified as ratio between Cav-1 and $\beta$-actin, used as a house-keeping gene (right panel). SEM values are indicated by vertical bars. 

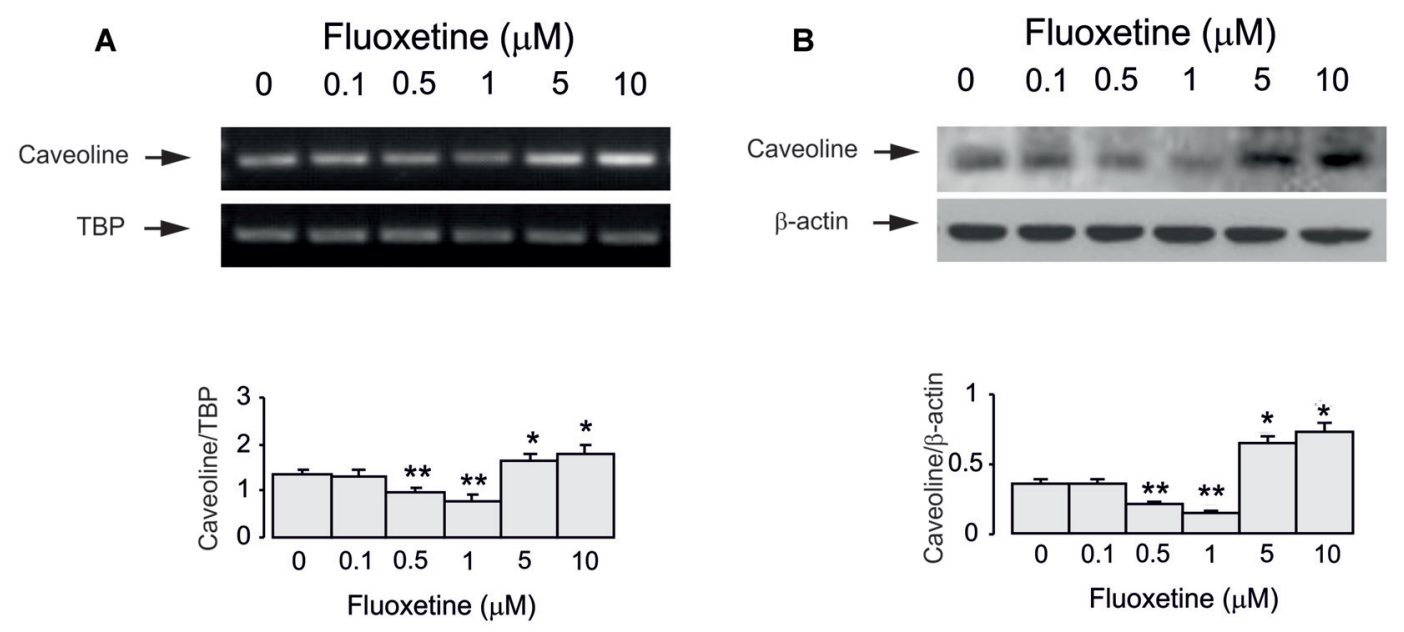

FIGURE 3 | Regulation of mRNA and protein expression of Cav-1 by chronic treatment with fluoxetine in astrocytes. Cells were incubated for 2 weeks in the absence of any drug (0 $\mu \mathrm{M}$ fluoxetine, control) or in the presence of $0.1,0.5,1,5$, or $10 \mu \mathrm{M}$ fluoxetine. (A) Southern blot from representative experiment. Similar results were obtained from three independent experiments. Average mRNA expression was quantified as ratio between Cav-1 and TBP, used as a house-keeping gene.

(B) Immunoblot from a representative experiment. Similar results were obtained from three independent experiments. Average protein expression was quantitated as ratio between Cav-1 and $\beta$-actin, used as a house-keeping gene. SEM values are indicated by vertical bars. ${ }^{*}$ Indicates statistically significant $(P<0.05)$ difference from $0,0.1,0.5$ and $1 \mu \mathrm{M}$ fluoxetine; **indicates statistically significant $(P<0.05)$ difference from all other groups but not from each other.

La Jolla, CA, USA. First antibody raised against Cav-1 was from Cell Signaling Technology (Danvers, MA, USA). HRP conjugated IgG second antibodies and U0126 (1,4-diamino2,3-dicyano-1,4-bis[2-aminophe-nylthio]butadiene) were from Promega (Madison, WI, USA). ECL detection reagents were from Amersham Biosciences (Buckinghamshire, UK).

\section{Data Analysis}

All values were expressed as mean \pm SEM. Data were primarily analyzed for homogeneity of variance using SPSS 17.0 software (Chicago, IL, USA), and $p$ values of analysis were $>0.05$, from 0.373 to 0.722 . Statistical significance between groups was determined by a one-way analysis of variance (ANOVA) followed by Fisher's least significant difference (LSD) for multiple comparisons using GraphPad Prism 5 software (La Jolla, CA, USA). $P$ values of less than 0.05 were considered statistically significant.

\section{RESULTS}

\section{Acute Treatment}

\section{Phosphorylation of AKT and ERK $\mathrm{E}_{1 / 2}$}

Acute treatment with fluoxetine for $20 \mathrm{~min}$ induced phosphorylation of AKT $(148 \% \pm 5.2 \%$ of control at 0.5 $\mu \mathrm{M}$ and $198 \% \pm 7.5 \%$ of control at $10 \mu \mathrm{M})$ and $\mathrm{ERK}_{1 / 2}$ (from $196 \% \pm 6.1 \%$ of control for $\mathrm{ERK}_{1}$ and $184 \% \pm 5.5 \%$ for $\mathrm{ERK}_{2}$ at $5 \mu \mathrm{M}$; from $202 \% \pm 8.3 \%$ of control for $\mathrm{ERK}_{1}$ and $190 \% \pm 6.9 \%$ for $\mathrm{ERK}_{2}$ at $10 \mu \mathrm{M}$ ) in a concentrationdependent manner with no effect at $0.1 \mu \mathrm{M}$ (Figures 1A,B). However, the lowest concentration of fluoxetine stimulating AKT phosphorylation at $0.5 \mu \mathrm{M}$ is 10 times lower than the concentration significantly stimulating $\mathrm{ERK}_{1 / 2}$ phosphorylation
$(5 \mu \mathrm{M})$. This is in agreement with our previous findings (Li et al., 2008, 2009).

\section{mRNA and Protein Expression of c-Fos and FosB}

Acute treatment with fluoxetine for $1 \mathrm{~h}$ regulated expression of mRNA for immediate early genes c-Fos in a biphasic concentration-dependent manner, with no effect at $0.1 \mu \mathrm{M}$ (Figure 2A). Fluoxetine caused significant down-regulation of mRNA for c-Fos at 0.5 and $1 \mu \mathrm{M}$ whereas at 5 and $10 \mu \mathrm{M}$ a significant up-regulation of mRNA was observed (Figure 2A). The lowest level of c-Fos expression was detected at $1 \mu \mathrm{M}$ being $52.6 \% \pm 3.2 \%$ of control, whereas the highest level of expression was determined at $10 \mu \mathrm{M}$ being $147.8 \%$ of control group. Expression of mRNA for FosB was up-regulated by fluoxetine at 5 and $10 \mu \mathrm{M}$ (mRNA levels were increased by $49.4 \% \pm 7.9 \%$ and $61.7 \% \pm 5.7 \%$ of the control) with no down-regulation at 0.5 and $1 \mu \mathrm{M}$. Inhibitor of MAPK U0126 suppressed an increase of mRNA expression of c-Fos and FosB by 5 and $10 \mu \mathrm{M}$ fluoxetine, but had no effect on the c-Fos down-regulation at 0.5 and $1 \mu \mathrm{M}$ fluoxetine (Figure 2A). Inhibitor of PI3K LY294002, suppressed the decrease of mRNA expression of c-Fos at 0.5 and $1 \mu \mathrm{M}$ fluoxetine but had no effect on the increase of mRNA levels at 5 and $10 \mu \mathrm{M}$ fluoxetine (Figure 2A).

Similar results were also obtained for protein expression of c-Fos and FosB after $4 \mathrm{~h}$ treatment with fluoxetine (Figure 2B). Fluoxetine at 0.5 and $1 \mu \mathrm{M}$ decreased the protein expression of c-Fos, with the lowest expression at $0.5 \mu \mathrm{M}$ being $40.4 \% \pm 4.7 \%$ of control group, but at 5 and $10 \mu \mathrm{M}$ significantly increased the protein level of c-Fos. The highest level of expression was detected at $10 \mu \mathrm{M}$ being $232.7 \% \pm 9.2 \%$ of control group. Again, at lower concentrations, fluoxetine had no inhibitory effect on FosB protein expression. Treatment with U0126 abolished increased protein expression of c-Fos and FosB by 5 and $10 \mu \mathrm{M}$ 


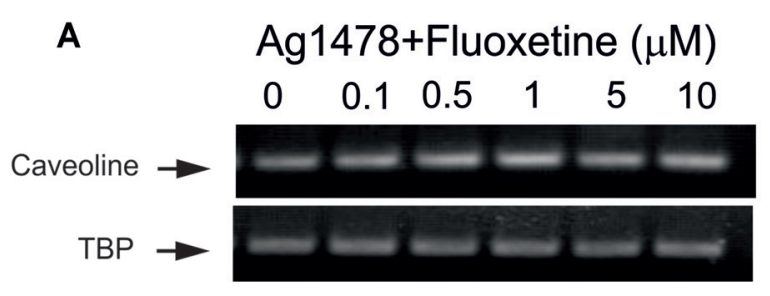

B

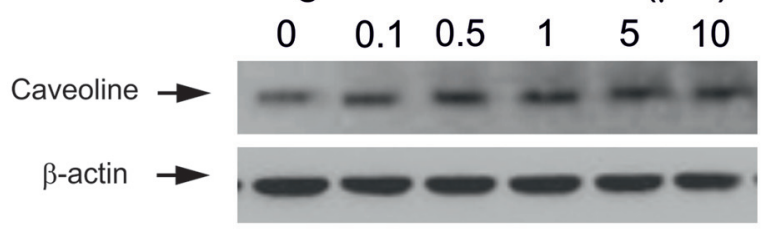

C
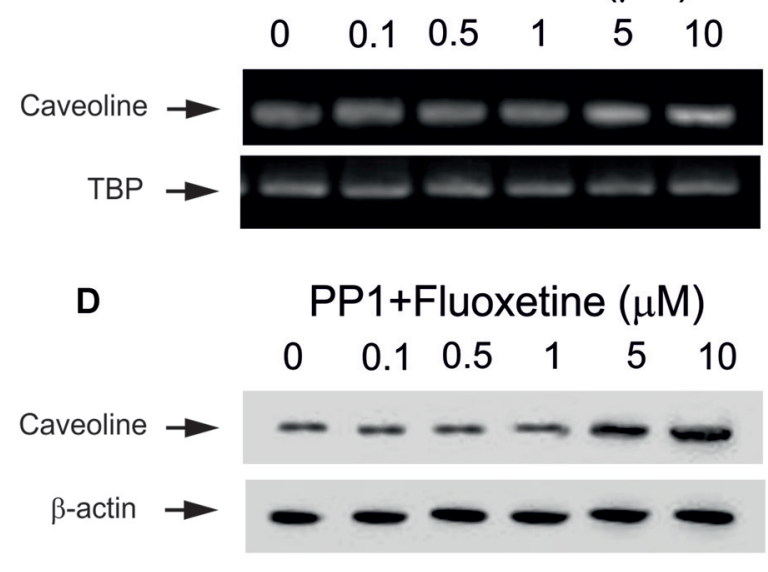

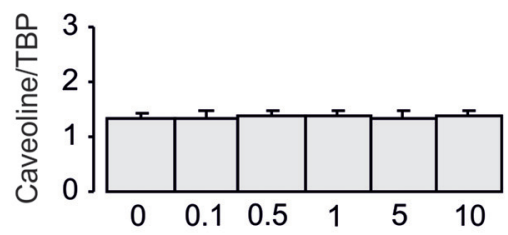

Ag1478+Fluoxetine $(\mu \mathrm{M})$
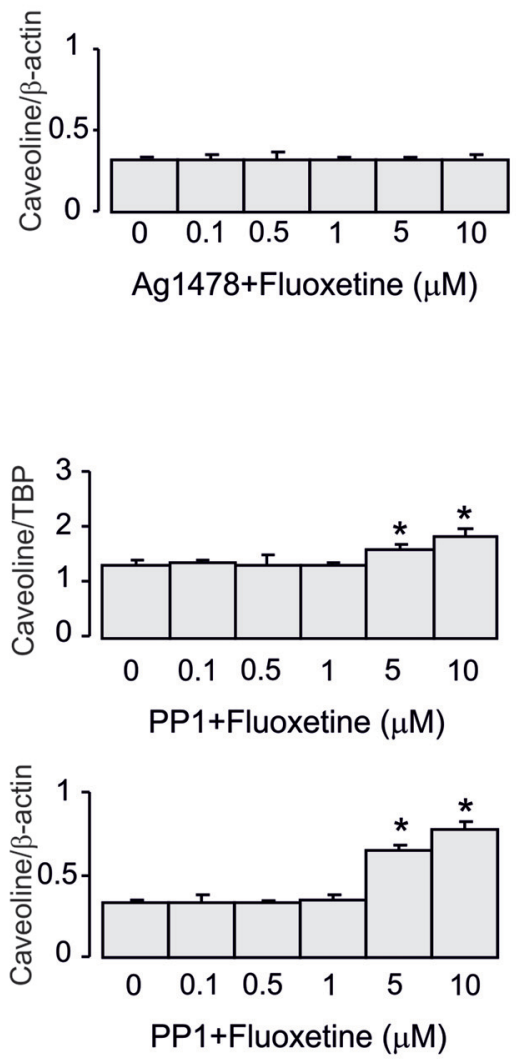

FIGURE 4 | Regulation of mRNA and protein expression of Cav-1 by chronic treatment with fluoxetine requires epidermal growth factor receptor (EGFR) or Src activation in astrocytes. Cells were incubated for 2 weeks without any drug $(0 \mu \mathrm{M}$ fluoxetine, control) or with $0.1,0.5,1,5$, or $10 \mu \mathrm{M}$ fluoxetine in the presence of AG1478, an inhibitor of EGFR or PP1, an inhibitor of Src. (A,C) Southern blots from representative experiments. Similar results were obtained from three independent experiments. Average mRNA expression was quantitated as ratio between Cav-1 and TBP, used as a house-keeping gene. (B,D) Immunoblots from a representative experiments. Similar results were obtained from three independent experiments. Average protein expression was quantified as ratio between Cav-1 and $\beta$-actin, used as a house-keeping gene. SEM values are indicated by vertical bars. *Indicates statistically significant $(P<0.05)$ difference from all other groups but not from each other.

fluoxetine, but had no effect on the expression decrease induced by 0.5 and $1 \mu \mathrm{M}$ fluoxetine. In contrast, LY294002, an inhibitor of PI3K, suppressed the decrease of mRNA expression of c-Fos by 0.5 and $1 \mu \mathrm{M}$ fluoxetine but had no effect on increased mRNA expression in the presence of 5 and $10 \mu \mathrm{M}$ fluoxetine (Figure 2B).

\section{Protein Content of Cav-1}

Acute treatment with fluoxetine at concentrations of $0.1,0.5$, 1 , 5, or $10 \mu \mathrm{M}$ for $1 \mathrm{~h}$ had no effect on protein level of Cav-1 $(0.1 \mu \mathrm{M}, 113.5 \% \pm 16.2 \%$ of control; $0.5 \mu \mathrm{M}$,
$121.6 \% \pm 10.8 \%$ of control; $1 \mu \mathrm{M}, 111 \% \pm 13.5 \%$ of control; $5 \mu \mathrm{M}, 94.6 \% \pm 10.7 \%$ of control; $10 \mu \mathrm{M}, 105.4 \% \pm 16.2 \%$ of control; Figure 2C).

\section{Chronic Treatment}

\section{Gene Expression of Cav-1}

Treatment of cultured astrocytes with fluoxetine for 2 weeks regulated expression of Cav-1 protein in a concentrationdependent manner with $0.1,0.5$ and $1 \mu \mathrm{M}$ fluoxetine causing a significant down-regulation but 5 and $10 \mu \mathrm{M}$ a significant up-regulation (Figure 3), which agrees well with our previous 


\section{A \\ U0126+Fluoxetine $(\mu \mathrm{M})$}
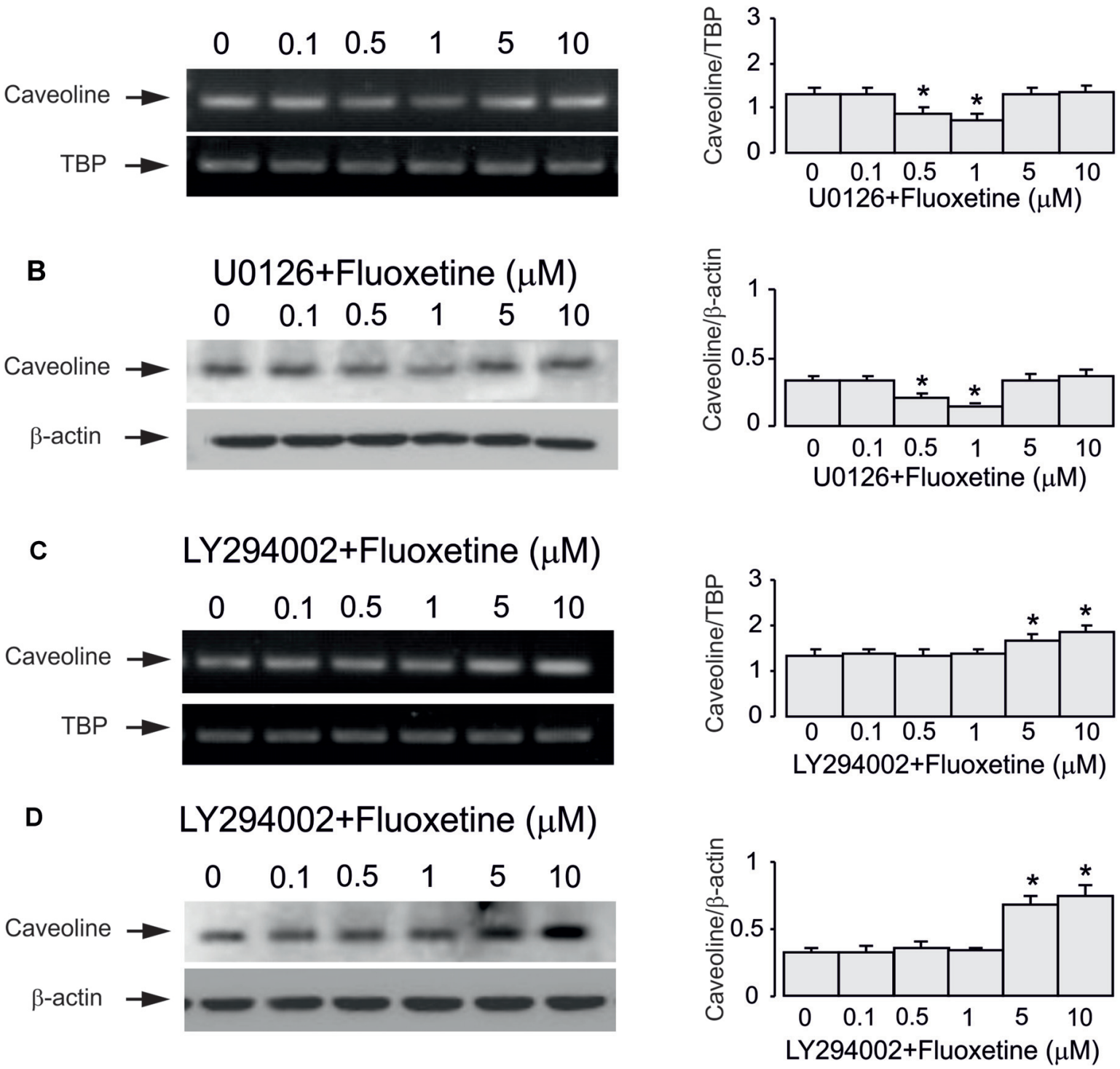

FIGURE 5 | Regulation of mRNA and protein expression of Cav-1 by chronic treatment with fluoxetine requires ERK or AKT activation in astrocytes. Cells were incubated for 2 weeks without any drug (0 $\mu \mathrm{M}$ fluoxetine, control) or with $0.1,0.5,1,5$, or $10 \mu \mathrm{M}$ fluoxetine in the presence of U0126, an inhibitor of MEK or LY294002, an inhibitor of PI3K. (A,C) Southern blots from representative experiments. Similar results were obtained from three independent experiments. Average mRNA expression was quantified as ratio between Cav-1 and TBP, used as a house-keeping gene. (B,D) Immunoblots from a representative experiments. Similar results were obtained from three independent experiments. Average protein expression was quantified as ratio between Cav-1 and $\beta$-actin, used as a house-keeping gene. SEM values are indicated by vertical bars. *Indicates statistically significant $(P<0.05)$ difference from all other groups but not from each other.

findings (Bai et al., 2017). The lowest level was observed at $1 \mu \mathrm{M}$ being $40.9 \% \pm 4.5 \%$ of control, whereas the highest level of expression was determined at $10 \mu \mathrm{M}$ being $137.9 \% \pm 5.7 \%$ of control group.

Inhibitor of EGFR AG1478 at $10 \mu \mathrm{M}$ abolished fluoxetine effects on Cav-1 mRNA and protein expression at both low and high concentrations $(0.5$ and $1 \mu \mathrm{M}, 101.5 \% \pm 3.1 \%$ and $102.2 \% \pm 2.7 \%$ of control; 5 and $10 \mu \mathrm{M}, 100.7 \% \pm 4.3 \%$ and $101.5 \% \pm 2.9 \%$ of control; Figures $4 \mathrm{~A}-\mathrm{D})$. Inhibitor of Src
PP1, at $10 \mu \mathrm{M}$ suppressed only effects of low concentrations of fluoxetine $(0.5$ and $1 \mu \mathrm{M}, 100.4 \% \pm 7.2 \%$ and $99.6 \% \pm 2.1 \%$ of control) without affecting action of high concentrations (5 and $10 \mu \mathrm{M}, 120.7 \% \pm 3.5 \%$ and $135.6 \% \pm 5.2 \%$ of control).

Inhibitor of MAPK U0126 at $10 \mu \mathrm{M}$ did not change fluoxetine effects on Cav-1 mRNA and protein expression at low concentrations $(0.5$ and $1 \mu \mathrm{M}, 65.7 \% \pm 4.1 \%$ and $60.0 \% \pm 4.7 \%$ of control) but abolished drug effects at high concentration (5 and $10 \mu \mathrm{M}, 99.3 \% \pm 3.9 \%$ and $101.5 \% \pm 3.7 \%$ of control; 


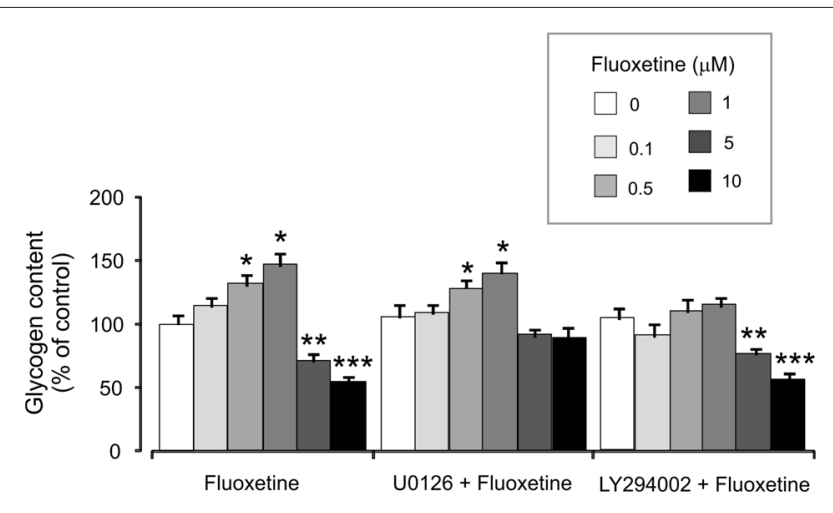

FIGURE 6 | Effect of fluoxetine on the glycogen content requires ERK or AKT activation in astrocytes. Cells were incubated for 2 weeks without any drug ( $0 \mu \mathrm{M}$ fluoxetine, control) or with $0.1,0.5,1,5$, or $10 \mu \mathrm{M}$ fluoxetine in the presence of U0126, an inhibitor of MEK or LY294002, an inhibitor of PI3K. After the experiment glycogen was determined by measuring glucose content fluorometrically before and after breakdown of remaining glycogen in astrocytes. Average glycogen contents are indicated as percentages of those under control conditions. SEM values are indicated by vertical bars. *Indicates statistically significant $(P<0.05)$ difference from 0 and $0.1 \mu \mathrm{M}$ groups but not from each other; **indicates statistically significant $(P<0.05)$ difference from $0,0.1,0.5$ and $1 \mu \mathrm{M}$ groups; ${ }^{* * *}$ indicates statistically significant $(P<0.05)$ difference from all other groups.

Figures 5A-D). In contrast, an inhibitor of PI3K LY294002 at $10 \mu \mathrm{M}$ abolished drug effect at low concentrations only ( 0.5 and $1 \mu \mathrm{M}, 99.3 \% \pm 3.4 \%$ and $102.2 \% \pm 2.5 \%$ of control) but had no effect on high concentrations (5 and $10 \mu \mathrm{M}, 100.7 \% \pm 3.8 \%$ and $101.5 \% \pm 3.5 \%$ of control).

\section{Glycogen Content}

Treatment with 0.5 and $1 \mu \mathrm{M}$ fluoxetine for 2 weeks increased glycogen content to $132.2 \% \pm 5.1 \%$ and $147.7 \% \pm 7.2 \%$ of the control group. In contrast, treatment with 5 and $10 \mu \mathrm{M}$ fluoxetine decreased glycogen content to $72.4 \% \pm 5.3 \%$ and $55.2 \% \pm 5.1 \%$ of the control (Figure 6). It is in agreement with our previous findings (Bai et al., 2017). Inhibitor of MAPK U0126 at $10 \mu \mathrm{M}$ did not change fluoxetine effects on glycogen content at low concentrations $(0.5$ and $1 \mu \mathrm{M}, 130.2 \% \pm 6.2 \%$ and $141.2 \% \pm 8.2 \%$ of control) but inhibited drug effects at high concentration (5 and $10 \mu \mathrm{M}, 92.3 \% \pm 5.2 \%$ and $89.3 \% \pm 9.2 \%$ of control). In contrast, an inhibitor of PI3K LY294002 at 10 $\mu \mathrm{M}$ abolished drug effect at low concentrations only (0.5 and 1 $\mu \mathrm{M}, 111.4 \% \pm 5.4 \%$ and $115.2 \% \pm 7.1 \%$ of control) but had no effect on high concentrations ( 5 and $10 \mu \mathrm{M}, 77.2 \% \pm 4.8 \%$ and $57.1 \% \pm 4.1 \%$ of control).

\section{DISCUSSION}

Caveolae and caveolin proteins are known to contribute to a various diseases, such as Alzheimer's disease, Parkinson's disease, cardiovascular and prion diseases, systemic lupus erythematosus and HIV (Michel et al., 2007). Although no report exists about caveolin contribution to major depression the Cav-1 is linked to schizophrenia in both human polymorphism study (Najafipour et al., 2014) and in Cav-1 knockout animals (Allen et al., 2011).

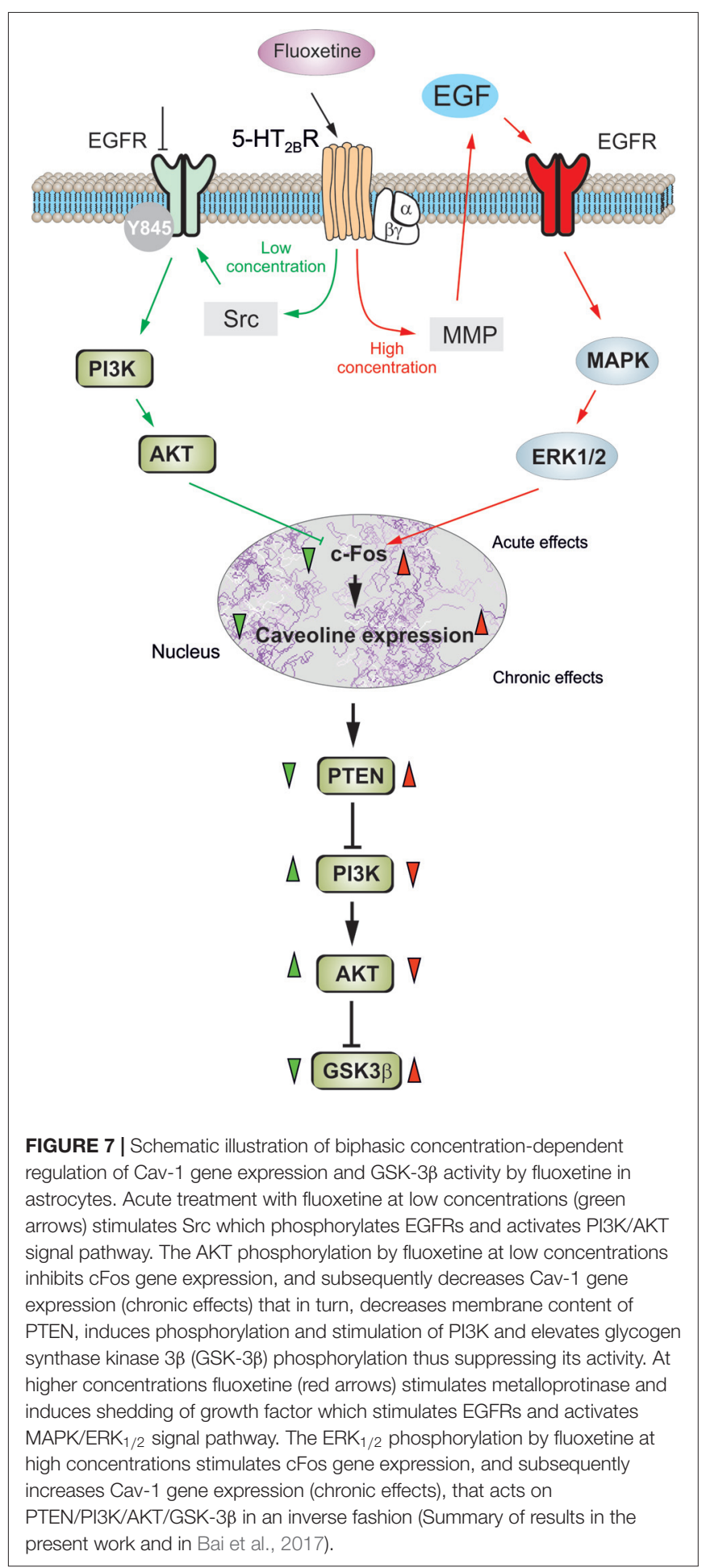

Caveolin proteins are key modulators of a variety of neuronal intracellular signaling pathways (Stern and Mermelstein, 2010). In the brain, Cav-1 is found to play a key role in estrogeninduced, glutamate-independent activation of metabotropic glutamate receptors (mGluRs) that regulate multiple neuronal and glial functions (Meitzen and Mermelstein, 2011). In addition, Cav-1 in astrocytes is associated with reactivity (Niesman et al., 
2014), with SorLA, a protein with sorting and trafficking functions and demonstrated relevance to Alzheimer's disease (Salgado et al., 2012), with expression of connexin Cx43 (Strale et al., 2012), and with fatty acid-binding proteins (FABPs)-related signals (Kagawa et al., 2015). We have reported that chronic treatment of astrocytes with ammonium increases Cav-1 gene expression and membrane PTEN content decreases activity of PI3K/AKT, and suppresses GSK3 $\beta$ phosphrylation that results in the increase of its activity (Wang et al., 2017). Recently, we have found that chronic treatment with fluoxetine regulates Cav-1/PTEN/PI3K/AKT/GSK-3 $\beta$ signaling pathway in primary cultures of astrocytes with bi-phasic concentration dependence (Bai et al., 2017). The GSK-3 $\beta$ is involved in diverse signaling pathways, such as insulin/insulin-like growth factor (IGF-1) signaling, neurotrophic factor signaling, and the Wnt signaling (Gould and Manji, 2005). Since high levels of GSK-3 $\beta$ activity are generally associated with mood disorders (Gould and Manji, 2005), the underlying mechanisms of the bi-phasic concentration dependence become important. In addition, these mechanisms may be also applicable to the regulation of expression of other genes by fluoxetine.

In the present study we found that acute treatment with fluoxetine stimulated AKT phosphorylation at concentrations of $0.5 \mu \mathrm{M}$ or higher; for $\mathrm{ERK}_{1 / 2}$ phosphorylation the concentration has to be as high as $5 \mu \mathrm{M}$, which is in agreement with our previously report ( $\mathrm{Li}$ et al., 2008, 2009). Chronic treatment of cultured astrocytes with low $(0.5-1 \mu \mathrm{M})$ concentrations of fluoxetine decreased, whereas chronic treatment with high (5 and $10 \mu \mathrm{M})$ concentrations increased expression of Cav-1 mRNA and protein. Inhibitor of EGFR AG1478 abolished drug effects at all concentrations, indicating that both down- and up-regulation of Cav-1 gene expression are mediated by fluoxetine-induced EGFR transactivation, as we reported previously ( $\mathrm{Li}$ et al., 2008, 2009). In contrast, the Src inhibitor PP1 suppressed fluoxetine effects only at low concentrations, suggesting that at lower concentrations fluoxetine-induced transactivation of EGFR involves Src phosphorylation of Y845, which leads to downstream signaling to the PI3K/AKT pathway (Nair and Sealfon, 2003).

Subsequently, we found that down-regulation of Cav-1 gene expression by lower concentrations of fluoxetine was inhibited by the PI3K inhibitor, LY294002 but not by MAPK inhibitor, U0126; the up-regulation of Cav-1 by higher drug concentrations was inhibited by MAPK inhibitor, U0126 but not by PI3K inhibitor, LY294002. Furthermore, the mRNA expression of c-Fos but not FosB after $1 \mathrm{~h}$ treatment and protein expression of c-Fos but not FosB after $4 \mathrm{~h}$ treatment were down-regulated by lower concentrations of fluoxetine was inhibited by the PI3K inhibitor, LY294002 but not by MAPK inhibitor, U0126. The up-regulation by higher drug concentrations was suppressed by MAPK inhibitor, U0126 but not by PI3K inhibitor, LY294002. These data suggest that at lower concentrations of fluoxetine AKT inhibits c-Fos gene expression, which in turn, down-regulates Cav-1 gene expression. At higher concentrations $\mathrm{ERK}_{1 / 2}$ stimulates cFos gene expression, which in turn, up-regulates Cav-1 gene expression. Since fluoxetine at lower concentrations has no effect on FosB expression, FosB may not be involved in regulation of Cav-1 gene expression in astrocytes. The distinct effects of AKT and $E K_{1 / 2}$ on c-Fos expression was also reported by in human pre-B cells (Anbazhagan et al., 2013). Although it is well known that ERK $\mathrm{ER}_{1 / 2}$ stimulates c-Fos gene expression, the reports about AKT-induced inhibition are rare and the underlying mechanism is unknown. It has been reported that Cav-1 inhibits Ras/MAPK/ERK $1 / 2$ cascade (Engelman et al., 1998; Galbiati et al., 1998) and AP-1 transcription factor activation (Engelman et al., 1997; Williams et al., 2004). Further study confirms that Cav-1 reduces activation of $\mathrm{ERK}_{1 / 2}$ that, in turn, decreases expression and activation of c-Fos and c-Jun proteins in PAM212 cells (Trimmer et al., 2013). In the present study, acute treatment with fluoxetine for $1 \mathrm{~h}$ had no effect on protein level of Cav-1, suggesting that Cav-1induced variation of $\mathrm{c}$-fos expression is not involved in the effects of fluoxetine in astrocytes.

The regulation of GSK-3 $\beta$ phosphorylation and activity will change the activity of glycogen synthetase, which, in turn, affects glycogen content in astrocytes. Previously, we found that fluoxetine increased glycogen content in cultured astrocytes at lower concentrations, but decreased it at higher concentrations (Bai et al., 2017). Here, we found that increased glycogen content by lower concentrations of fluoxetine was inhibited by the PI3K inhibitor, LY294002 but not by MAPK inhibitor, U0126; decreased glycogen content by higher drug concentrations was inhibited by MAPK inhibitor, U0126 but not by PI3K inhibitor, LY294002. It is in agreement with the drug effects on Cav-1 gene expression, and further suggests that biphasic regulation of GSK-3 $\beta$ activity by chronic treatment with fluoxetine is via concentration-dependent drug effects on two distinct signal pathways, PI3K/AKT and MAPK/ERK. Regulation of glycogen may contribute to behavioral effects of SSRIs. Glycogen turnover, i.e., interspersed glycogen synthesis and glycogenolysis, is indispensable to support learning (Gibbs and Hutchinson, 2012; Hertz et al., 2013). The acute memoryenhancing, glycogenolysis-dependent effect of both fluoxetine and paroxetine has been characterized (O'Dowd et al., 1994, 1995; Suzuki et al., 2011; Gibbs and Hertz, 2014; Gao et al., 2016). Knock-out of brain GS abolishes learning of new motor and cognitive skills (Duran et al., 2013).

In conclusion, fluoxetine at low concentrations stimulates Src which, phosphorylates EGFRs and activates PI3K/AKT signal pathway, but at high concentrations stimulates metalloproteinase and induces shedding of growth factor which stimulates EGFRs and activates MAPK/ERK $\mathrm{E}_{1 / 2}$ signaling pathway (Li et al., 2008; Figure 7). Mechanisms underlying biphasic concentrationdependent regulation of Cav-1 gene expression by fluoxwtine in astrocytes are: (i) inhibition of cFos gene expression by $\mathrm{AKT}$ at lower concentrations; and (ii) increase of c-Fos gene expression by $\mathrm{ERK}_{1 / 2}$ at higher concentrations. These opposing effects of $\mathrm{PI} 3 \mathrm{~K} / \mathrm{AKT}$ and $\mathrm{MAPK} / \mathrm{ERK}_{1 / 2}$ signaling pathways are fundamental for the biphasic concentration-dependent regulation of GSK3 $\beta$ activity by fluoxetine (Bai et al., 2017). Since the complex roles of Cav-1, the effects of fluoxetine on regulation of Cav-1 gene expression may significantly affect astrocytic functions and signals. Bi-phasic regulation of Cav-1 gene expression in astrocytes, as well as other types of cells 
in peripheral tissues may contribute to both therapeutic and side effects of the drug. Selective inhibition of PI3K/AKT or MAPK/ERK $1 / 2$ signal pathway may provide opportunity to avoid non-therapeutic effects of the drug.

\section{AUTHOR CONTRIBUTIONS}

LP conceived and designed the experiments. BL, SJ, TY, LY and $\mathrm{CH}$ performed the experiments. BL, SJ, LY and LP analyzed the data. AV, LP and BL drafted the manuscript, which was critically revised and finally approved by LP and AV. All authors agree to be accountable for all aspects of the work in ensuring that questions related to the accuracy or integrity of any part of the work are appropriately investigated and resolved.

\section{REFERENCES}

Allen, J. A., Yadav, P. N., Setola, V., Farrell, M., and Roth, B. L. (2011). Schizophrenia risk gene CAV1 is both pro-psychotic and required for atypical antipsychotic drug actions in vivo. Transl. Psychiatry 1:e33. doi: 10.1038/tp. 2011.35

Anbazhagan, K., Rabbind Singh, A., Isabelle, P., Stella, I., Céline, A. D., Bissac, E., et al. (2013). Human pre-B cell receptor signal transduction: evidence for distinct roles of PI3kinase and MAP-kinase signalling pathways. Immun. Inflamm. Dis. 1, 26-36. doi: 10.1002/iid3.4

Bai, Q., Song, D., Gu, L., Verkhratsky, A., and Peng, L. (2017). Bi-phasic regulation of glycogen content in astrocytes via Cav-1/PTEN/PI3K/AKT/GSK-3 $\beta$ pathway by fluoxetine. Psychopharmacology 234, 1069-1077. doi: 10.1007/s00213-0174547-3

Cameron, P. L., Ruffin, J. W., Bollag, R., Rasmussen, H., and Cameron, R. S. (1997). Identification of caveolin and caveolin-related proteins in the brain. J. Neurosci. 17, 9520-9535.

Duran, J., Saez, I., Gruart, A., Guinovart, J. J., and Delgado-García, J. M. (2013). Impairment in long-term memory formation and learningdependent synaptic plasticity in mice lacking glycogen synthase in the brain. J. Cereb. Blood Flow Metab. 33, 550-556. doi: 10.1038/jcbfm. 2012.200

Elkeles, A., Juven-Gershon, T., Israeli, D., Wilder, S., Zalcenstein, A., and Oren, M. (1999). The c-fos proto-oncogene is a target for transactivation by the p53 tumor suppressor. Mol. Cell. Biol. 19, 2594-2600. doi: 10.1128/MCB. 19.4.2594

Engelman, J. A., Chu, C., Lin, A., Jo, H., Ikezu, T., Okamoto, T., et al. (1998). Caveolin-mediated regulation of signaling along the p42/44 MAP kinase cascade in vivo: a role for the caveolin-scaffolding domain. FEBS Lett. 428, 205-211. doi: 10.1016/s0014-5793(98)00470-0

Engelman, J. A., Wykoff, C. C., Yasuhara, S., Song, K. S., Okamoto, T., and Lisanti, M. P. (1997). Recombinant expression of caveolin-1 in oncogenically transformed cells abrogates anchorage-independent growth. J. Biol. Chem. 272, 16374-16381. doi: 10.1074/jbc.272.26.16374

Galbiati, F., Volonte, D., Engelman, J. A., Watanabe, G., Burk, R., Pestell, R. G., et al. (1998). Targeted downregulation of caveolin-1 is sufficient to drive cell transformation and hyperactivate the p42/44 MAP kinase cascade. EMBO J. 17, 6633-6648. doi: 10.1093/emboj/17.22.6633

Gao, V., Suzuki, A., Magistretti, P. J., Lengacher, S., Pollonini, G., Steinman, M. Q., et al. (2016). Astrocytic $\beta_{2}$-adrenergic receptors mediate hippocampal long-term memory consolidation. Proc. Natl. Acad. Sci. U S A 113, 8526-8531. doi: $10.1073 /$ pnas. 1605063113

Gibbs, M. E., and Hertz, L. (2014). Serotonin mediation of early memory formation via $5-\mathrm{HT}_{2 \mathrm{~B}}$ receptor-induced glycogenolysis in the day-old chick. Front. Pharmacol. 5:54. doi: 10.3389/fphar.2014.00054

Gibbs, M. E., and Hutchinson, D. S. (2012). Rapid turnover of glycogen in memory formation. Neurochem. Res. 37, 2456-2463. doi: 10.1007/s11064-012 $-0805-2$

\section{FUNDING}

This study was supported by Grant No. 31171036 to LP from the National Natural Science Foundation of China.

\section{SUPPLEMENTARY MATERIAL}

The Supplementary Material for this article can be found online at: https://www.frontiersin.org/articles/10.3389/fncel. 2017.00335/full\#supplementary-material

FIGURE S1 | Representative original images for the antibodies used in this study. (A) p-ERK, (B) ERK, (C) p-AKT, (D) AKT, (E) c-Fos and FosB and (F) Cav-1.

Gould, T. D., and Manji, H. K. (2005). Glycogen synthase kinase-3: a putative molecular target for lithium mimetic drugs. Neuropsychopharmacology 30, 1223-1237. doi: 10.1038/sj.npp.1300731

Hertz, L., Li, B., Song, D., Ren, J., Dong, L., Chen, Y., et al. (2012). Astrocytes as a 5-HT $\mathrm{H}_{2 \mathrm{~B}}$-Mediated SSRI, SERT-independent target, slowly altering depressionassociated genes and function. Curr. Signal Transduct. Ther. 7, 65-80. doi: $10.2174 / 1574362799278154$

Hertz, L., Peng, L., and Lai, J. C. (1998). Functional studies in cultured astrocytes. Methods 16, 293-310. doi: 10.1006/meth.1998.0686

Hertz, L., Song, D., Li, B., Du, T., Xu, J., Gu, L., et al. (2014). Signal transduction in astrocytes during chronic or acute treatment with drugs (SSRIs, antibipolar drugs, GABA-ergic drugs and benzodiazepines) ameliorating mood disorders. J. Signal Transduct. 2014:593934. doi: 10.1155/2014/593934

Hertz, L., Xu, J., Song, D., Yan, E., Gu, L., and Peng, L. (2013). Astrocytic and neuronal accumulation of elevated extracellular $\mathrm{K}^{+}$with a $2 / 3 \mathrm{~K}^{+} / \mathrm{Na}^{+}$ flux ratio-consequences for energy metabolism, osmolarity and higher brain function. Front. Comput. Neurosci. 7:114. doi: 10.3389/fncom.2013.00114

Hsieh, S.-R., Hsu, C.-S., Lu, C.-H., Chen, W.-C., Chiu, C.-H., and Liou, Y.M. (2013). Epigallocatechin-3-gallate-mediated cardioprotection by Akt/GSK$3 \beta /$ caveolin signalling in $\mathrm{H} 9 \mathrm{c} 2$ rat cardiomyoblasts. J. Biomed. Sci. 20:86. doi: 10.1186/1423-0127-20-86

Inoue, D., Kido, S., and Matsumoto, T. (2004). Transcriptional induction of FosB/DeltaFosB gene by mechanical stress in osteoblasts. J. Biol. Chem. 279, 49795-49803. doi: 10.1074/jbc.m404096200

Kagawa, Y., Yasumoto, Y., Sharifi, K., Ebrahimi, M., Islam, A., Miyazaki, H., et al. (2015). Fatty acid-binding protein 7 regulates function of caveolae in astrocytes through expression of caveolin-1. Glia 63, 780-794. doi: 10.1002/glia.22784

Kong, E. K., Peng, L., Chen, Y., Yu, A. C., and Hertz, L. (2002). Up-regulation of $5-\mathrm{HT}_{2 \mathrm{~B}}$ receptor density and receptor-mediated glycogenolysis in mouse astrocytes by long-term fluoxetine administration. Neurochem. Res. 27, 113-120. doi: 10.1023/A:1014862808126

Lajoie, P., and Nabi, I. R. (2010). Lipid rafts, caveolae, and their endocytosis. Int. Rev. Cell Mol. Biol. 282, 135-163. doi: 10.1016/S1937-6448(10)82003-9

Li, B., Zhang, S., Li, M., Hertz, L., and Peng, L. (2009). Chronic treatment of astrocytes with therapeutically relevant fluoxetine concentrations enhances $\mathrm{CPLA}_{2}$ expression secondary to $5-\mathrm{HT}_{2 \mathrm{~B}}$-induced, transactivation-mediated ERK $_{1 / 2}$ phosphorylation. Psychopharmacology 207, 1-12. doi: 10.1007/s00213009-1631-3

Li, B., Zhang, S., Zhang, H., Nu, W., Cai, L., Hertz, L., et al. (2008). Fluoxetinemediated $5-\mathrm{HT}_{2 \mathrm{~B}}$ receptor stimulation in astrocytes causes EGF receptor transactivation and ERK phosphorylation. Psychopharmacology 201, 443-458. doi: 10.1007/s00213-008-1306-5

Marjou, A. E., Delouvée, A., Thiery, J. P., and Radvanyi, F. (2000). Involvement of epidermal growth factor receptor in chemically induced mouse bladder tumour progression. Carcinogenesis 21, 2211-2218. doi: 10.1093/carcin/21.12.2211

Meier, E., Hertz, L., and Schousboe, A. (1991). Neurotransmitters as developmental signals. Neurochem. Int. 19, 1-15. doi: 10.1016/01970186(91)90113-r 
Meitzen, J., and Mermelstein, P. G. (2011). Estrogen receptors stimulate brain region specific metabotropic glutamate receptors to rapidly initiate signal transduction pathways. J. Chem. Neuroanat. 42, 236-241. doi: 10.1016/j. jchemneu.2011.02.002

Michel, M., Lone, Y.-C., Centlivre, M., Roux, P., Wain-Hobson, S., and Sala, M. (2007). Optimisation of secretion of recombinant HBsAg virus-like particles: impact on the development of HIV-1/HBV bivalent vaccines. Vaccine 25, 1901-1911. doi: 10.1016/j.vaccine.2006.08.014

Moskovich, O., Herzog, L. O., Ehrlich, M., and Fishelson, Z. (2012). Caveolin1 and dynamin- 2 are essential for removal of the complement C5b-9 complex via endocytosis. J. Biol. Chem. 287, 19904-19915. doi: 10.1074/jbc.m111. 333039

Nair, V. D., and Sealfon, S. C. (2003). Agonist-specific transactivation of phosphoinositide 3-kinase signaling pathway mediated by the dopamine D2 receptor. J. Biol. Chem. 278, 47053-47061. doi: 10.1074/jbc.m303 364200

Najafipour, R., Heidari, A., Alizadeh, S. A., Ghafelebashi, H., Rashvand, Z., Javadi, A., et al. (2014). Association between upstream purine complexes of human caveolin-1 gene and schizophrenia in qazvin province of iran. Iran. Red Crescent Med. J. 16:e21484. doi: 10.5812/ircmj.21484

Niesman, I. R., Schilling, J. M., Shapiro, L. A., Kellerhals, S. E., Bonds, J. A., Kleschevnikov, A. M., et al. (2014). Traumatic brain injury enhances neuroinflammation and lesion volume in caveolin deficient mice. J. Neuroinflammation 11:39. doi: 10.1186/1742-2094-11-39

O'Dowd, B. S., Barrington, J., Ng, K. T., Hertz, E., and Hertz, L. (1995). Glycogenolytic response of primary chick and mouse cultures of astrocytes to noradrenaline across development. Dev. Brain Res. 88, 220-223. doi: 10.1016/0165-3806(95)00084-q

O’Dowd, B. S., Gibbs, M. E., Ng, K. T., Hertz, E., and Hertz, L. (1994). Astrocytic glycogenolysis energizes memory processes in neonate chicks. Dev. Brain Res. 78, 137-141. doi: 10.1016/0165-3806(94) 90018-3

Peng, L., and Huang, J. (2012). Astrocytic 5- $\mathrm{HT}_{2 \mathrm{~B}}$ receptor as in vitro and in vivo target of SSRIs. Recent Pat. CNS Drug Discov. 7, 243-253. doi: 10.2174/157488912803252078

Peng, L., Li, B., and Verkhratsky, A. (2016). Targeting astrocytes in bipolar disorder. Expert. Rev. Neurother. 16, 649-657. doi: 10.1586/14737175.2016. 1171144

Salgado, I. K., Serrano, M., García, J. O., Martínez, N. A., Maldonado, H. M., Báez-Pagán, C. A., et al. (2012). SorLA in glia: shared subcellular distribution patterns with caveolin-1. Cell. Mol. Neurobiol. 32, 409-421. doi: 10.1007/s10571-011-9771-5

Silva, W. I., Maldonado, H. M., Velázquez, G., García, J. O., and González, F. A. (2007). Caveolins in glial cell model systems: from detection to significance. J. Neurochem. 103, 101-112. doi: 10.1111/j.1471-4159.2007.04712.x

Stern, C. M., and Mermelstein, P. G. (2010). Caveolin regulation of neuronal intracellular signaling. Cell. Mol. Life Sci. 67, 3785-3795. doi: 10.1007/s00018010-0447-y

Strale, P. O., Clarhaut, J., Lamiche, C., Cronier, L., Mesnil, M., and Defamie, N. (2012). Down-regulation of Connexin43 expression reveals the involvement of caveolin-1 containing lipid rafts in human U251 glioblastoma cell invasion. Mol. Carcinog. 51, 845-860. doi: 10.1002/mc.20853

Suzuki, A., Stern, S. A., Bozdagi, O., Huntley, G. W., Walker, R. H., Magistretti, P. J., et al. (2011). Astrocyte-neuron lactate transport is required for long-term memory formation. Cell 144, 810-823. doi: 10.1016/j.cell.2011. 02.018

Takizawa, N., Sawada, S., Chosa, N., Ishisaki, A., and Naruishi, K. (2013). Secreted caveolin-1 enhances periodontal inflammation by targeting gingival fibroblasts. Biomed. Res. 34, 1-11. doi: 10.2220/biomedres.34.1

Trimmer, C., Bonuccelli, G., Katiyar, S., Sotgia, F., Pestell, R. G., Lisanti, M. P., et al. (2013). Cav1 suppresses tumor growth and metastasis in a murine model of cutaneous SCC through modulation of MAPK/AP-1 activation. Am. J. Pathol. 182, 992-1004. doi: 10.1016/j.ajpath.2012.11.008

Verkhratsky, A., Rodríguez, J. J., and Steardo, L. (2014). Astrogliopathology: a central element of neuropsychiatric diseases. Neuroscientist 20, 576-588. doi: $10.1177 / 1073858413510208$

Wang, W., Gu, L., Verkhratsky, A., and Peng, L. (2017). Ammonium increases TRPC1 expression via Cav-1/PTEN/AKT/GSK3 $\beta$ pathway. Neurochem. Res. 42, 762-776. doi: 10.1007/s11064-016-2004-z

Williams, T. M., Lee, H., Cheung, M. W., Cohen, A. W., Razani, B., Iyengar, P., et al. (2004). Combined loss of INK4a and caveolin-1 synergistically enhances cell proliferation and oncogeneinduced tumorigenesis: role of INK4a/CAV-1 in mammary epithelial cell hyperplasia. J. Biol. Chem. 279, 24745-24756. doi: $10.1074 /$ jbc.m402064200

Xia, H., Khalil, W., Kahm, J., Jessurun, J., Kleidon, J., and Henke, C. A. (2010). Pathologic caveolin-1 regulation of PTEN in idiopathic pulmonary fibrosis. Am. J. Pathol. 176, 2626-2637. doi: 10.2353/ajpath.2010.091117

Yue, L., and Mazzone, T. (2011). Endogenous adipocyte apolipoprotein E is colocalized with caveolin at the adipocyte plasma membrane. J. Lipid. Res. 52, 489-498. doi: 10.1194/jlr.m011809

Zebrowski, E. J., Pylypas, S. P., Odlum, O., and Johnson, R. B. (1994). Comparative metabolism of $3 \mathrm{H}$-glucosamine by fibroblast populations exposed to cyclosporine. J. Periodontol. 65, 565-567. doi: 10.1902/jop.1994. 65.6.565

Zhang, S., Li, B., Lovatt, D., Xu, J., Song, D., Goldman, S. A., et al. (2010). 5-HT2B receptors are expressed on astrocytes from brain and in culture and are a chronic target for all five conventional 'serotonin-specific reuptake inhibitors'. Neuron Glia Biol. 6, 113-125. doi: 10.1017/s1740925x10000141

Conflict of Interest Statement: The authors declare that the research was conducted in the absence of any commercial or financial relationships that could be construed as a potential conflict of interest.

Copyright (๑) 2017 Li, Jia, Yue, Yang, Huang, Verkhratsky and Peng. This is an open-access article distributed under the terms of the Creative Commons Attribution License (CC BY). The use, distribution or reproduction in other forums is permitted, provided the original author(s) or licensor are credited and that the original publication in this journal is cited, in accordance with accepted academic practice. No use, distribution or reproduction is permitted which does not comply with these terms. 